\title{
INTEGRASI MODEL MONTESSORI PADA SISWA TUNAGRAHITA RINGAN: EKSPLORASI, DESAIN DAN IMPLEMENTASI DALAM MATERI PERKALIAN
}

\section{INTEGRATION OF MONTESSORI MODEL IN MILD RETARDED STUDENTS: EKSPLORATION, DESIGN AND IMPLEMENTATION ON MULTIPLICATION MATERIAL}

\author{
Mellawaty $^{1}$, Lusi Siti Aisah ${ }^{2}$ \\ ${ }^{1}$ Universitas Wiralodra, Jalan Ir. H. Juanda KM 3 Indramayu, mellawaty@unwir.ac.id \\ ${ }^{2}$ Universitas Wiralodra, Jalan Ir. H. Juanda KM 3 Indramayu, lusisitiaisah@ unwir.ac.id
}

\begin{abstract}
ABSTRAK
Penelitian ini mengintegrasikan Model Montessori pada siswa tunagrahita ringan dengan tujuan untuk mengasumsikan persiapan guru matematika pada materi perkalian. Metode penelitian menggunakan pendekatan ADDIE (Analysis, Design, Development, Implementation, and Evaluation). Tahaan yang digunakan dalam penelitian ini terdiri dari (1) eksplorasi; (2) desain; (3) pengembangan; dan (4) implementasi. Teknik analisis data (1) kualitatif dilakukan untuk studi eksplorasi, menggambarkan desain dan proses pengembangan; (2) kuantitatif dilakukan untuk menyelidiki hasil implementasi Model Montessori pada siswa tunagrahita ringan dalam materi perkalian. Berdasarkan hasil penelitian, menunjukkan bahwa: (1) langkah-langkah Model Montessori dapat digunakan pada pelajaran matematika untuk menjelaskan materi perkalian. (2) tahap desain dan pengembangan terdiri dari merancang konsep integrasi, dan pengembangan sistem pembelajaran. (3) hasil analisis implementasi dapat: (a) membantu meningkatkan kegiatan interaksi pembelajaran; (b) meningkatkan konsep matematika pada materi perkalian; (c) memberikan informasi kepada guru matematika di SLB yang terkait pembelajaran berbasis Metode Montessori.
\end{abstract}

Kata Kunci : metode montessori, tunagrahita ringan, perkalian.

\begin{abstract}
This study integrated the Montessori Model in mild retarded students with the aim to assume the preparation of mathematics teachers on multiplication material. Research methods using ADDIE (Analysis, Design, Development, Implementation, and Evaluation). The stages used in this study consisted of (1) exploration; (2) design; (3) development; and (4) implementation. (1) Qualitative data analysis technique used for exploratory studies, design analysis and development processes;

(2) Quantitative is done to evaluate the results of the implementation of the Montessori Model in mild retarded students in multiplication material. Based on the results of the study, showed that: (1) the steps of the Montessori Model can be used in mathematics to explain multiplication material. (2) development of learning design, and development of learning system. (3) the results of the implementation analysis can: (a) help improve learning interaction activities; (b) improve mathematical concepts in multipication material; (c) provide information to mathematics teachers in special schools related to learning media based on the Montessori Method.
\end{abstract}

Keyword(s): montessori method, mild mental retardation, multipication.

How to Cite: Mellawaty \& Aisah, L. S. (2019). Integrasi Model Montessori Pada Siswa Tunagrahita Ringan: Eksplorasi, Desain dan Implementasi Dalam Materi Perkalian. Mathline: Jurnal Matematika dan Pendidikan Matematika, Vol.4, No.2, 139-147. 


\section{DOI:}

\section{PENDAHULUAN}

Pendidikan merupakan salah satu modal penting yang dibutuhkan oleh setiap individu untuk menjalankan kehidupannya sebagai seorang manusia. Pendidikan merupakan hak setiap manusia sebagai warga negara, tanpa melihat strata sosial ataupun ekonominya. Hal tersebut telah tercantum di dalam Undang-Undang Dasar 1945 Pasal 31 Ayat 1 menyebutkan, tiap-tiap warga negara berhak mendapatkan pendidikan. Hal tersebut menyiratkan bahwa, pendidikan tidak hanya diperuntukkan untuk warga negara yang sehat secara fisik dan mental. Setiap manusia di dunia, menginginkan dirinya terlahir sebagai manusia yang normal, utuh, tidak mempunyai kekurangan satu hal apapun baik dari kondisi fisik ataupun mental. Tetapi, tidak semua manusia terlahir sesuai dengan keinginan mereka. Beberapa diantaranya terlahir dalam kondisi yang tidak sempurna, misalkan salah satunya adalah seseorang yang mengalami tunagrahita.

Tunagrahita merupakan suatu kondisi dimana seseorang tidak mampu untuk bersosialisasi dikarenakan gangguan dalam memproses informasi yang diterimanya dengan informasi yang dia miliki sebelumnya. Hal tersebut disebabkan oleh sel neuronnya yang tidak berfungsi dengan baik, sehingga mereka membutuhkan bantuan orang lain untuk memahami serta mengolah informasi tersebut. Pendapat diatas serupa dengan pendapat dari Lai \& Rivera J (2012) yang menyebutkan bahwa tunagrahita adalah ketidakmampuan syaraf perkembangan sehingga mengganggu kemampuan untuk bersosialisasi, berkomunikasi, memproses informasi, dan juga menyebabkan keterbatasan pengalaman untuk memperhatikan masa depannya, sering melakukan tindakan yang sama secara berulang-ulang.

Akan tetapi, keadaan tersebut bukanlah suatu alasan bagi orang tua, pemerintah, ataupun masyarakat untuk lepas tangan dari permasalahan tersebut. Kita harus membantu mereka untuk mendapatkan kehidupan yang baik semaksimal mungkin bagi mereka, salah satunya dari aspek pendidikan. Pendidikan untuk Anak dengan Berkebutuhan Khusus (ABK) berada di Pendidikan Luar Biasa, dan Sekolah Luar Biasa merupakan instansi yang memberikan pelayanan pendidikannya. Sejalan dengan pendapat Awalia dan Mahmudah (2016) menyebutkan SLB sebagai salah satu lembaga penyelenggaraan pendidikan khusus sebaiknya memberikan layanan khusus agar siswa tunagrahita ringan dapat mengembangkan keterampilan sosialnya. Dari pendapat diatas, didapatkan informasi 
bahwa hal tersebut diharapkan dapat memberikan manfaat bagi siswa tunagrahita ringan agar mampu hidup mandiri dan mereka dapat diterima oleh masyarakat sekitar tanpa memandang mereka sebelah mata.

Menurut Suhardi (2016), jumlah siswa baru menurut jenis ketunaan dari Sekolah Dasar Luar Biasa sampai Sekolah Menengah Luar Biasa, untuk siswa tunagrahita di Provinsi Jawa Barat berjumlah 2.695 siswa pada tahun akademik 2015/2016 di sekolah negeri dan swasta. Hal tersebut tidak sebanding dengan jumlah Sekolah Luar Biasa yang berada di Provinsi Jawa Barat, dimana pada tahun 2015/2016 berjumlah 353 untuk sekolah berstatus negeri dan swasta. Kabupaten Indramayu merupakan salah satu kabupaten di Provinsi Jawa Barat yang berbatasan dengan Pantai Utara dan beberapa kota lain di sekitarnya. Disnaker Kabupaten Indramayu menyebutkan bahwa Indramayu merupakan kabupaten yang mempunyai luas wilayah 2000,99 $\mathrm{km}^{2}$. Kabupaten Indramayu hanya memiliki sedikit Sekolah Luar Biasa (SLB) dan itu pun hanya berada di Ibukota Kabupatennya. Hal tersebut menjadi salah satu penyebab, dimana para penyandang tunagrahita di wilayah Indramayu pinggiran khususnya, tidak pernah mendapatkan kesempatan untuk merasakan pendidikan yang mana, pendidikan tersebut merupakan hak mereka sebagai warga negara.

SLB sebagai salah satu tempat untuk menyelenggarakan pendidikan khusus bagi Anak Berkebutuhan Khusus (ABK), diharapkan dapat memberikan layanan pendidikan yang baik sehingga anak-anak tunagrahita ringan mampu mengembangkan kemampuankemampuan mereka, baik kemampuan dalam bidang akademik, pribadi ataupun sosial. Sehingga, mereka dapat diterima oleh lingkungan sekitar serta mampu untuk hidup mandiri. Bahkan, lebih diharapkan lagi setelah mereka lulus sekolah, mereka mampu untuk hidup bersosialisasi dengan masyarakat.

Menurut Kementerian Pendidikan dan Kebudayaan Republik Indonesia (2012: 3) tentang Kurikulum Sekolah dikemukakan bahwa Sekolah Luar Biasa (SLB) dibedakan menjadi 3 jenis yaitu :

a) Sekolah Luar Biasa A diperuntukkan bagi anak-anak tunanetra yaitu anak-anak yang tidak dapat melihat karena indra penglihatannya mengalami kerusakan.

b) Sekolah Luar Biasa B diperuntukkan bagi anak-anak tunarungu yaitu anak-anak yang tidak dapat mendengar karena indera penglihatannya mengalami kerusakan.

c) Sekolah Luar Biasa C diperuntukkan bagi anak-anak tunagrahita yaitu anak-anak yang mengalami cacat pikiran dan lemah daya tangkap (idiot).

d) Sekolah Luar Biasa D diperuntukkan bagi anak-anak tunadaksa. 
e) Sekolah Luar Biasa E diperuntukkan bagi anak-anak tunalaras.

f) Sekolah Luar Biasa G diperuntukkan bagi anak-anak mengalami cacat ganda.

Di beberapa desa di Kecamatan Kroya, Kabupaten Indramayu, terdapat beberapa anak penyandang tunagrahita, mulai dari tunagrahita ringan sampai ke tunagrahita sangat berat. Tetapi, karena keterbatasan ekonomi, sarana, dan jauhnya letak SLB, menjadikan mereka tumbuh menjadi anak penyandang tunagrahita yang tidak pernah mempunyai kesempatan untuk dapat belajar. Diharapkan, apabila mereka mendapatkan kesempatan untuk belajar di sekolah formal, mereka mampu untuk hidup mandiri dan diterima oleh masyarakat sekitar. Sebagai contoh, Jingga (nama samaran), nama dari salah satu anak tunagrahita ringan di salah satu desa di Kecamatan Kroya, merupakan anak sepertinya apabila dia mendapatkan pendidikan, dia akan mampu untuk hidup mandiri. Dia sering mengikuti teman-temannya yang normal pergi ke sekolah. Tetapi, dia hanya sampai di sebuah gubuk dan menunggu temannya pulang sekolah. Di gubuk tersebut, dia belajar menulis sendiri di buku yang dia bawa dari rumahnya. Dia tidak pernah mendapatkan kesempatan untuk belajar di SLB.

Kemampuan intelektual anak tunagrahita ringan yang berada di bawah rata-rata membuat mereka mengalami kesulitan belajar dan kesulitan dalam menerima pelajaran, khususnya pada pelajaran matematika. Mengajarkan matematika pada anak tunagrahita ringan akan lebih berhasil jika menggunakan sesuatu yang konkret, contoh-contoh sederhana, bahasa yang mudah mereka pahami, dan dilakukan dengan situasi yang menarik serta menyenangkan supaya mereka tidak jenuh serta termotivasi untuk belajar.

DePorter \& Hernacki (1999) mengemukakan tentang cara belajar yang intinya cara belajar merupakan suatu kombinasi dari bagaimana ia menyerap, dan kemudian mengatur serta mengolah informasi. Cara belajar anak tunagrahita ringan berbeda dengan anak normal. Anak tunagrahita ringan memiliki kemampuan dan kondisi emosional yang berbeda dengan anak normal. Agar tujuan pengajaran tercapai, guru juga harus mengetahui cara belajar siswa. Guru perlu memahami kesulitan dan kebiasaan siswa. Anak tunagrahita ringan pada umumnya mengalami kesulitan dalam memecahkan soal yang tidak diimbangi dengan pemahaman konsep operasi hitung dalam matematika. Oleh karena itu, guru harus mengetahui kesulitan belajar siswa dapat mengatasi kesulitan belajar yang dialami oleh siswa.

Berikut ini dikemukakan beberapa hasil penelitian yang relevan dengan penelitian ini. Hasil penelitian Senjaya, dkk (2016) menemukan bahwa gaya belajar siswa tunagrahita 
ringan pada materi perkalian di sekolah yaitu $25 \%$ bertipe visual dan $75 \%$ bertipe kinestetik. Sedangkan gaya belajar siswa tunagrahita ringan pada materi perkalian dirumah yakni $25 \%$ bertipe visual, $25 \%$ bertipe auditori, dan $50 \%$ bertipe kinestetik. Dengan mengetahui gaya belajar siswa, maka dapat digunakan strategi pembelajaran yang tepat dan sesuai, sehingga proses belajar lebih aktif dan efektif, sehingga siswa dapat memahami penjelasan yang diberikan. Penelitian Annas dan Fatimahningsih (2012) menyatakan bahwa pola pendidikan khusus bagi siswa SLB adalah pendidikan mata pelajaran umum dengan memberikan mata pelajaran umum menggunakan bahasa verbal dan non-verbal serta demonstrasi atau pemberian contoh. Dengan pendidikan keahlian dan bina diri yang diberikan, diharapkan siswa memiliki keahlian dan keterampilan khusus agar mampu mengurus dirinya sendiri, tidak bergantung pada oranglain. Selain dengan hal-hal tersebut, dengan dilakukannya motivasi serta pendekatan yang intensif pada ABK, diharapkan mereka mampu mengikuti kegiatan belajar dengan baik, dapat berkomunikasi dengan teman, guru, orangtua, dan orang-orang disekitarnya.

Berdasarkan penelitian yang berkaitan dengan proses belajar di SLBN II Indramayu, didapatkan beberapa masalah yang belum terselesaikan. Salah satunya adalah penerapan metode yang tepat dalam pembelajaran matematika berdasarkan gaya belajar tunagrahita ringan. Oleh karena itu, dalam penelitian ini akan dibuat rancangan RPP, silabus, dan alat peraga yang berbasis metode Montessori. Diharapkan dari hasil penelitian ini mampu menjadikan mereka manusia yang mampu dan diterima oleh masyarakat sekitar, dengan mengaplikasikan nilai-nilai matematika dan meningkatkan keterampilan dalam hidup.

\section{METODE PENELITIAN}

Bagian metode penelitian ini menguraikan langkah-langkah penyelesaian masalah. Uraikan dengan jelas prosedur penelitian yang dilakukan.

Tahapan penelitian ini mengacu pada pendekatan ADDIE (Analysis, Design, Development, Implementation, Evaluation) dengan tahapan (1) analisis eksplorasi; (2) pendesainan; (3) pengembangan; dan (4) implementasi, Branch,RM, dan Kopcha, TJ (2014). Pada tahap pertama, dilakukan studi eksplorasi Metode Montessori. Studi ini dilakukan dengan cara menelusuri literatur-literatur Metode Montessori dari berbagai sumber bacaan. Tahap kedua dilakukan pendesainan dengan memperhatikan kebutuhan pengguna, tujuan pembelajaran dan tingkat penguasaan materi pembelajaran. Tahap ketiga, dilakukan pengembangan model pembelajaran dan kemudian dilakukan validasi oleh lima 
validator yaitu ahli materi, ahli media, dan ahli pembelajaran. tahap keempat, dilakukan implementasi terbatas penggunaan Model Montessori kepada siswa tunagrahita ringan semester satu berjumlah 4 siswa di SLB N II Indramayu. Instrumen yang digunakan dalam penelitian ini yaitu lembar observasi, lembar validasi, angket kepuasan, dan tes penguasaan materi perkalian. Teknik analisis data; (1) kualitatif digunakan ntuk studi eksplorasi, menggambarkan desain dan proses pengembangan; (2) kuantitatif dilakukan untuk menyelidiki hasil implementasi penggunaan Model Montessori pada materi perkalian.

\section{HASIL DAN PEMBAHASAN}

Adapun hasil penelitian dan pembahasan yang didapatkan dari penelitian yang telah dilakukan, yaitu:

\section{Fase Analisis Eksplorasi}

Dalam proses belajar mengajar pada pelajaran matematika, tidak hanya didukung oleh satu atau dua unsur saja. Tetapi, melibatkan berbagai unsur yaitu meliputi guru, siswa, kurikulum, bahan ajar, media pembelajaran, dan lain-lain yang tergabung dalam sebuah sistem. Unsur-unsur tersebut saling berkaitan satu sama lain dalam menentukan keberhasilan suatu proses belajar mengajar. Hal tersebut berlaku juga pada proses belajar mengajar untuk siswa tunagrahita ringan di SLB.

Dalam pembelajaran matematika, guru dihadapkan pada beberapa masalah dalam mentransfer pengetahuannya kepada siswa tunagrahita ringan dengan proses yang menarik, agar siswa tunagrahita ringan tersebut mampu menerima informasi yang disampaikan kepada mereka. Apalagi siswa tunagrahita ringan merupakan siswa yang kemampuannya berbeda dengan siswa normal pada umumnya. Berdasarkan hasil analisis terhadap penelusuran dan studi pustaka terkait dengan model pembelajaran untuk siswa tunagrahita ringan, didapatkan Metode Montessori. Dimana sebenarnya Metode Montessori pada awalnya memang diperuntukkan bagi anak-anak berkebutuhan khusus. Tetapi, seiring perkembangan zaman, banyak yang mengadopsi langkah-langkah Metode Montessori untuk diterapkan pada siswa usia dini. Dan pada akhirnya, banyak orang yang mengetahui bahwa Metode Montessori adalah sebuah metode yang fokusnya pada perkembangan anak di usia dini.

\section{Fase Desain dan Pengembangan}

Pada tahap ini, terdiri dari tahap pengintegrasian dari Metode Montessori khususnya pada materi perkalian, pendesainan dan pengembangan berbasis Metode Montessori. Adapun langkahnya yaitu: 
1) Guru mengajak siswa belajar dengan menggunakan alat peraga "KOMON" yaitu Kotak Montessori

2) Guru menjelaskan bagian-bagian pada alat peraga KOMON.

3) Guru menjelaskan kalau kelereng mewakili angka yang akan dikalikan, itu diletakkan pada lingkaran-lingkaran yang tersedia.

4) Guru mengajak siswa menghitung kelereng untuk mendapatkan hasilnya.

5) Guru meminta siswa untuk menuliskan hasilnya pada kertas.

\section{Fase Implementasi}

Hasil implementasi penggunaan pembelajaran materi perkalian menggunakan Metode Montessori menunjukkan adanya peningkatan aktivitas siswa tunagrahita ringa. Aktivitas siswa tunagrahita ringan yang diamati dalam penelitian ini adalah: (1) aktivitas dalam proses belajar materi perkalian; (2) aktivitas dalam mengerjakan latihan soal; (3) aktivitas dalam berdiskusi; (4) aktivitas dalam teknik bertanya. Hasil observasi interaksi aktivitas siswa tunagrahita pada pertemuan pertama diperoleh persentase $45,7 \%$ dan termasuk kedalam kategori cukup aktif. Sedangkan pada pertemuan ketiga, diperoleh persentase sebesar 58,5\% dan termasuk kedalam kategori cukup aktif. Adapun peningkatan aktivitas siswa tunagrahita ringan pada pembelajaran materi perkalian dengan Metode Montessori adalah sebesar 12,8\%.

Berdasarkan hasil penelitian ini, diperoleh fakta bahwa siswa tunagrahita ringan memang masih memerlukan pendampingan yang lebih ekstra dari guru. Hal ini disebabkan oleh tingkat pemahaman mereka terhadap perlakuan yang diberikan selama proses pembelajaran, tidak semuanya mampu mereka serap secara maksimal, karena keterbatasan kemampuan memproses informasi dan mengaitkannya dengan informasi baru yang mereka peroleh. Sebagaimana yang dijelaskan oleh Lai \& Rivera (2012) yang menyebutkan bahwa tunagrahita adalah ketidakmampuan syaraf perkembangan sehingga mengganggu kemampuan untuk bersosialisasi, berkomunikasi, memproses informasi, dan juga menyebabkan keterbatasan pengalaman untuk memperhatikan masa depannya, sering melakukan tindakan yang sama secara berulang-ulang. Oleh karena itu, dalam mengajarkan materi perkalian kepada siswa tuna grahita ringan harus dilakukan dengan sabar dan berhati-hati serta jangan terlalu memaksakan siswa agar mampu menerima materi secara maksimal agar siswa tidak tertekan dalam proses belajar mengajar.

Selain itu, hasil penelitian ini juga sesuai dengan penelitian Utami (2014) bahwa saran kepada guru yang membelajarkan matematika kepada anak tunagrahita dan beberapa 
pihak yang terkait adalah guru hendaknya tidak menggunakan gerak dan irama hanya sebagai motivasi saja, akan tetapi menggunakan gerak dan irama sebagai strategi pembelajaran dalam membelajarkan pengetahuan konseptual dan prosedural matematika. Guru hendaknya menggunakan strategi penemuan terbimbing dengan meminta siswa untuk mempraktekan sendiri, bukan memberikan contoh terlebih dahulu.

Dengan pendidikan keahlian dan bina diri yang diberikan, diharapkan siswa memiliki keahlian dan keterampilan khusus agar mampu mengurus dirinya sendiri, tidak bergantung pada oranglain. Selain dengan hal-hal tersebut, dengan dilakukannya motivasi serta pendekatan yang intensif pada $\mathrm{ABK}$, diharapkan mereka mampu mengikuti kegiatan belajar dengan baik, dapat berkomunikasi dengan teman, guru, orangtua, dan orang-orang disekitarnya.

\section{KESIMPULAN}

Berdasarkan hasil penelitian, dapat disimpulkan bahwa:

(1) Langkah-langkah Model Montessori dapat digunakan pada pelajaran matematika untuk menjelaskan materi perkalian.

(2) Tahap desain dan pengembangan terdiri dari merancang konsep integrasi, dan pengembangan sistem pembelajaran.

(3) Hasil analisis implementasi dapat:

(a) Membantu meningkatkan kegiatan interaksi pembelajaran;

(b) Meningkatkan konsep matematika pada materi perkalian;

(c) Memberikan informasi kepada guru matematika di SLB yag terkait pembelajaran berbasis Metode Montessori.

Untuk penelitian selanjutnya, akan dilakukan penelitian penggunaan alat peraga "KOMON (Kotak Montessori)" tersebut pada kegiatan pembelajaran matematika tingkat ketunaan lainnya, yaitu tunanetra.

\section{UCAPAN TERIMAKASIH}

Pada kesempatan ini, kami mengucapkan banyak-banyak terimakasih kepada Kementerian Riset, Teknologi, dan Pendidikan Tinggi Republik Indonesia yang telah memberikan kesempatan kepada kami untuk mendapatkan hibah penelitian pada Skema Penelitian Dosen Pemula tahun anggaran 2018/2019. Kami ucapkan terimakasih juga kepada pimpinan dan jajaran SLB N II Indramayu, yang telah memberikan kesempatan kepada kami untuk meneliti di institusi tersebut. Tidak lupa juga kami mengucapkan 
terimakasih kepada Ketua LLDIKTI IV, Rektor Universitas Wiralodra, Kepala LPPM Universitas Wiralodra, beserta seluruh jajarannya, yang selalu mendukung seluruh dosennya untuk melakukan kegiatan penelitian sebagai bagian dari kegiatan wajib yang harus dilakukan oleh seorang dosen, dalam kegiatan Tri Dharma Perguruan Tinggi. Semoga, dengan adanya penelitian ini, kedepannya semakin banyak warga negara Indonesia, baik dari peneliti ataupun lainnya yang memberikan perhatian untuk pendidikan di SLB yang ada di seluruh Indonesia.

\section{DAFTAR PUSTAKA}

Annas dan Fatimahningsih. 2012. Pola Pendidikan Bagi Anak-Anak Penyandang Cacat Mental. Jurnal Sosiologi Universitas Lampung, Vol. 15, No. 2: 110-121.

Awalia, R. H dan Mahmudah, S. (2016). Studi Deskriptif Kemampuan Interaksi Sosial Anak Tunagrahita Ringan. Jurnal Pendidikan Khusus Universitas Negeri Surabaya.

Branch, RM dan Kopcha, TJ. (2014). Model Desain Pembelajaran. Handbook Penelitian tentang Komunikasi Pendidikan dan Teknologi.

DePorter, B., Hernacki, M., \& Abdurrahman, A. (1999). Quantum Learning: Membiasakan Belajar Nyaman dan Menyenangkan. Bandung: Kaifa.

Disnaker Indramayu. (2011). [online] Tersedia: http://disnakerkabindramayu.blogspot.com/p/profil-indramayu.html

Senjaya, dkk. 2017. Analisis Gaya Belajar Siswa Tunagrahita Ringan Materi Perkalian di Sekolah dan di Rumah. Journal of Medives. Volume 1, No. 1, Januari 2017, pp. 1-8.

Lai, Su, H. F. L \& Rivera, J. (2012). Effective Mathematics Strategies for Pre-School Children with Autism. ERIC, EJ978137. 17. 2., (p25-30).

Suhardi, D. (2016). Statistik Sekolah Luar Biasa (SLB) 2015/2016. Jakarta: PDSPK Kementerian Pendidikan dan Kebudayaan.

Undang-Undang Dasar 1945 Pasal 31 Ayat 1 tentang Pendidikan.

Undang-Undang Nomor 20 Tahun 2003 tentang Sistem Pendidikan Nasional.

Utami, A. D., Sujadi, I., \& Riyadi, R. (2014). Strategi guru dalam membelajarkan matematika pada materi lingkaran kepada anak tunagrahita. Jurnal Elektronik Pembelajaran Matematika, 2(8), 853- 864. 